\title{
PENERAPAN METODE TWO-STEP CLUSTER DALAM ANALISIS MENU ENGINEERING PADA USAHA KULINER
}

\author{
Nina Setiyawati*11, Dwi Hosanna Bangkalang² \\ ${ }^{1}$ Fakultas Teknologi Informasi, Universitas Kristen Satya Wacana, Salatiga \\ ${ }^{2}$ Fakultas Teknologi dan Desain, Universitas Bunda Mulia, Jakarta \\ Email: 1'nina.setiyawati@uksw.edu, ${ }^{2}$ dwihosanna@gmail.com \\ *Penulis Korespondensi
}

(Naskah masuk: 15 Mei 2019, diterima untuk diterbitkan: 10 Februari 2020)

\begin{abstract}
Abstrak
Dalam usaha kuliner, analisis menu perlu dilakukan untuk melihat keseimbangan antara food cost, harga menu, popularitas item, juga pertimbangan finansial dan pemasaran. Menu engineering merupakan metodologi untuk mengelompokkan menu berdasar pada margin kontribusi dan popularitas. Pada penelitian ini dilakukan analisis menu engineering pada suatu Usaha Mikro Kecil dan Menengah (UMKM) di Kota Salatiga yang bergerak di bidang kuliner menggunakan Two-Step Cluster yang dapat menggali cluster alami sesuai dengan kumpulan data menu yang ada sehingga akan ditemukan jumlah cluster yang optimal. Two-Step Cluster adalah metode yang dapat menangani variabel kategori dan kontinu, oleh karena itu dilakukanlah adaptasi model menu engineering yang diusulkan Kasavana dan Smith (1982) dengan menambahkan variabel category, sehingga dengan menggunakan Two-Step Cluster dapat dilihat mayoritas kategori menu yang menjadi anggota pada setiap cluster. Adaptasi juga dilakukan dalam kelompok variabel kontinu, yaitu dengan menambahkan variabel revenue yang digunakan untuk perbandingan pada hasil cluster. Dengan indikator Schwarz's Bayesian Information Criterion (BIC) dihasilkanlah jumlah cluster optimal yaitu 4 cluster dengan anggota paling sedikit pada cluster "popularitas tinggi dan mempunyai margin kontribusi yang berada di atas rata-rata". Pengujian clustering dilakukan dengan menggunakan metode Silhoutte dan menunjukkan kualitas cluster yang dihasilkan memiliki nilai Silhoutte yang besar yaitu 0,7 . Hal ini membuktikan cluster-cluster yang terbentuk telah terklasterisasi dengan baik. Adapun manfaat dari penelitian ini adalah didapatkannya rekomendasi kebijakan baru untuk setiap cluster yang dihasilkan sehingga dapat digunakan pemilik UMKM dalam upaya peningkatan revenue usaha.
\end{abstract}

Kata kunci: two-step cluster, menu engineering, analisis menu, UMKM

\section{THE IMPLEMENTATION OF TWO-STEP CLUSTERING METHOD IN MENU ENGINEERING ANALYSIS IN CULINARY BUSINESS}

\begin{abstract}
In culinary business, menu analysis is needed to see the balance of food cost, menu item prices, item popularity, as well as the financial and marketing considerations. Menu engineering is a method to group menu according to the contribution margin and popularity. The present study conducts a menu analysis to a Small Medium Enterprise (SME) in culinary business in Salatiga by implementing Two-Step Cluster analysis. It aims to find the natural clusters based on the existing menu data set to discover the optimal cluster number. Two-Step Cluster is a method that can be used to process categorical and continuous variables. In this study, the menu engineering model by Kasavana and Smith (1982) was adapted by adding the categorical variable. Therefore, by using the Two-Step Cluster method, the majority of menu category in each cluster can be seen. This adaption was also implemented in the continuous variable group by adding the revenue variable used for the comparison of the cluster results. With Schwarz's Bayesian Information Criterion (BIC) indicator, the results of the study show there are four clusters, in which "the highest popularity and the contribution margin above the average" cluster has the least members. Using Silhouette method, clustering testing was conducted, indicating the cluster quality result with 0,7 Silhouette value. As for the benefit of the study, new strategic recommendations can be generated for the resulted clusters based on which SME owners can improve their revenue.
\end{abstract}

Keywords: two-step cluster analysis, menu engineering, menu analysis, SME 


\section{PENDAHULUAN}

Dalam usaha kuliner, analisis menu perlu dilakukan untuk melihat keseimbangan antara food cost, harga menu, popularitas item, juga pertimbangan finansial dan pemasaran. Secara historis, terdapat beberapa model menu analisis yang memasukkan food cost, margin kontribusi dan popularitas atau campuran produk sebagai parameter (Taylor \& Brown, 2007). Menu engineering adalah model yang diperkenalkan oleh Kasavana dan Smith pada tahun 1982 yang merupakan modifikasi dari Menu Analysis Model yang dikembangkan oleh Miller (Taylor \& Brown, 2007). Menu engineering adalah metodologi untuk mengelompokkan menu berdasarkan margin kontribusi dan popularitas (LeBruto, Quain, \& Ashley, 1995) yang mencakup pendekatan peningkatan kinerja menu (Aktinson \& Jones, 1994), sehingga menu engineering dapat dikatakan sebagai suatu alat manajerial yang cocok dalam dunia kuliner (Cohen, Mesika, \& Schwartz, 1998). Analisis menu engineering juga merupakan suatu proses yang penting dalam perencanaan menu sehingga menjadi salah satu dasar dalam pertimbangan tujuan dan target anggaran (Seyitoglu, 2016).

Pada penelitian An Improved Method of Menu Planning (Linassi, Alberton, \& Marinho, 2016) membahas bagaimana analisis Menu Engineering (ME) bersama Activity-Based Costing (ABC) untuk meningkatkan profit dan pendapatan bisnis. Analisis $\mathrm{ME} / \mathrm{ABC}$ dapat memberikan kontrol kepada pihak manajemen dalam mengidentifikasi masalah maupun potensi kerugian yang dihasilkan tiap item menu ataupun grup item, begitu pula mengetahui item yang memberikan potensi pendapatan terbesar. Penelitian lain (Raab \& Mayer, 2007) menjelaskan bahwa ME/ABC memungkinkan pihak manajemen untuk mengklasifikasi tiap item sesuai dengan populatitas dan profit lebih baik dibandingkan dengan traditional ME.

Pada penelitian ini dilakukan analisis menu pada suatu Usaha Mikro Kecil dan Menengah (UMKM) di Kota Salatiga yang bergerak di bidang kuliner menggunakan metode Two-Step Cluster. Analisis Two-Step Cluster merupakan salah satu metode cluster yang dirancang untuk menyingkapkan cluster alami dari kumpulan data yang sebelumnya tidak terlihat (Wu, Zhan, Zhang, \& Deng, 2016). Pengklasteran akan dilakukan berdasarkan indeks popularitas dan margin kontribusi untuk mengevaluasi item-item menu yang ada. Pada traditional ME menu dikategorikan berdasarkan matriks kuadran (Linassi, Alberton, \& Marinho, 2016) sedangkan Two-Step Cluster akan menggali kesamaan item atau cluster alami yang tidak terlihat dari kumpulan data menu tersebut. Kelebihan lain dari Two-Step Cluster adalah dapat memproses data kategori dan kontinu (Wu, Zhan, Zhang, \& Deng, 2016), sehingga dapat menghasilkan cluster yang lebih spesifik sesuai kebutuhan. Two-Step Cluster juga dapat menentukan jumlah cluster yang paling optimal (Wu, Zhan, Zhang, \& Deng, 2016; Li \& Sun, 2018). Selain itu Two-Step Cluster memberikan informasi tentang pentingnya setiap variabel dalam pembangunan cluster tertentu (Mooi \& Sarstedt, 2011), di mana hal tersebut merupakan fitur menarik tambahan dibandingkan dengan metode pengklasteran tradisional (Soriano, Kozusznik, \& Peiro, 2018). Hasil dari penelitian ini diharapkan dapat memberikan pengetahuan kepada pihak manajemen dan memberikan rekomendasi kebijakan tiap kategori item yang ada sehingga dapat meningkatkan profit dan pendapatan bagi pihak UMKM.

\section{METODE PENELITIAN}

Penelitian ini melakukan adaptasi model menu engineering yang diusulkan oleh Kasavana dan Smith yang merupakan klasifikasi terhadap item menu dalam empat kuadran yang terbentuk dari matriks $2 \times 2$, yaitu popularitas rendah dan tinggi dengan margin kontribusi di bawah rata-rata dan di atas rata-rata (Kasavana, Smith, \& Schmidgall, 1990).

Adapun adaptasi yang dilakukan adalah dengan menambahkan 1 variabel kategori yaitu kategori item (category) untuk melihat kategori menu yang dominan pada setiap cluster yang terbentuk nantinya. Hal ini didukung dengan kelebihan metode Two-Step Cluster yaitu kemampuan menangani variabel kategori (Bicikova, 2014; Horn \& Huang, 2016). Adaptasi juga dilakukan dalam kelompok variabel kontinu, yaitu dengan menambahkan variabel pendapatan (revenue). Hal ini bertujuan untuk melihat pendapatan yang dihasilkan pada setiap cluster yang terbentuk nantinya.

Dengan adanya adaptasi yang dilakukan maka pada penelitian ini terdapat 1 variabel kategori yaitu kategori item (category) dan 3 variabel kontinu yaitu: 1) popularitas (popularity) yang merupakan jumlah item menu individual yang terjual dibandingkan dengan semua item yang terjual dalam kategori di mana item menu tersebut berada (Hayes \& Huffmann, 1985; Ojugo, 2009); 2) margin kontribusi (contribution margin) yang merupakan selisih harga jual item menu dengan biaya item menu (Hernowo, 2014; Ozdemir \& Caliskan, 2014); 3) pendapatan (revenue) yang merupakan hasil kali jumlah item menu terjual dengan harga jualnya (Ojugo, 2009), di mana variabel revenue juga digunakan untuk perbandingan pada hasil cluster.

Tahapan pada penelitian ini dibagi dalam 2 tahap utama yaitu Persiapan Data dan Two-Step Cluster, seperti terlihat pada Gambar 1. 


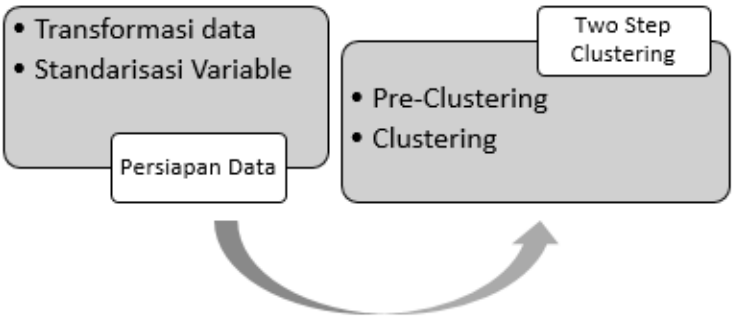

Gambar 1. Tahapan Penelitian

\subsection{Persiapan Data}

Data yang digunakan penelitian ini adalah data penjualan produk pada sebuah UMKM di kota Salatiga yang bergerak di bidang kuliner. Produk yang ada terdiri dari 95 item dan terdiri dari 3 category yaitu: 1) category 1 untuk menunjukkan item-item makanan; 2) category 2 untuk menunjukkan item-item minuman; 3) category 3 untuk menunjukkan item-item snack.

Seperti yang diilustrasikan pada Gambar 1, sebelum masuk ke tahapan analisis Two-Step Cluster, tahapan yang dilakukan adalah persiapan data yang terdiri dari dua proses yaitu transformasi data dan standarisasi variabel. Proses transformasi data diawali dengan melakukan cleaning pada basis data penjualan yaitu $\mathrm{db}$ cafes yang terdiri dari 24 tabel, dan didapatkan 3 tabel yang sesuai dengan kebutuhan clustering, yaitu tb menu, tb_kategori_menu, dan tb_detail_transaksi. Dari tabel-tabel tersebut dilakukanlah query untuk mendapatkan atribut baru yaitu popularitas, margin kontribusi dan pendapatan, yang kemudian digabung dalam satu tabel baru bersama atribut kategori menjadi data set untuk proses selanjutnya. Kode Program 1 adalah query untuk mendapatkan atribut pendapatan atau revenue.

Kode Program 1. Query untuk Atribut Revenue

SELECT to menu.nama menu,

sum(tb_detail_transaksi.qty*tb_menu.harga_jual) as revenue

FROM tb_detail_transaksi JOIN tb_menu ON

tb menu.id menu $=$ tb detail transaksi.id menu WHERE

tb_detail_transaksi.status_menu ='Selesai' and

to detail transaksi.subtotal bayar=

tb_detail_transaksi.subtotal_tagihan group by

tb_menu.nama_menu order by revenue DESC

Proses selanjutnya dilakukan standarisasi data pada variabel kontinu yang telah terbentuk (Bacher, Wenzig, \& Vogler, 2004; Şchiopu, 2010). Hasil standarisasi data pada variabel kontinu terlihat pada Tabel 1.

Tabel 1 merupakan tabel yang menunjukkan variabel kontinu terstandar. Standarisasi data dilakukan untuk mendapatkan skala parameter sesuai dengan ketentuan pada Two-Step Cluster saat proses pre-clustering. Two-Step Cluster menggunakan standar deviasi dari variabel kontinu sebagai skala parameternya.

\begin{tabular}{lclll}
\hline \multicolumn{5}{c}{ Tabel 1. Variabel Kontinu Terstandar } \\
\hline $\begin{array}{l}\text { Id } \\
\text { Item }\end{array}$ & Category & Popularity & $\begin{array}{l}\text { Contribution } \\
\text { Margin }\end{array}$ & Revenue \\
\hline 1 & 2 & 0.65362 & -1.70277 & -0.40559 \\
2 & 1 & -0.40383 & 0.07721 & -0.36945 \\
3 & 1 & 0.4717 & 0.07721 & 0.66315 \\
4 & 1 & -0.46069 & 0.07721 & -0.4365 \\
5 & 1 & 0.07373 & 0.07721 & 0.19379 \\
6 & 1 & -0.27876 & -0.55163 & -0.30722 \\
7 & 1 & -0.46069 & -1.13904 & -0.46254 \\
$\ldots \ldots$ & $\ldots$ & $\ldots$ & $\ldots$ & $\ldots$ \\
25 & 3 & 0.0851 & -1.06471 & -0.20852 \\
26 & 2 & -0.36972 & 0.38769 & -0.30484 \\
$\ldots$ & $\ldots$ & $\ldots$ & $\ldots$ & $\ldots$ \\
95 & 1 & -0.27876 & -1.47254 & -0.43212 \\
\hline
\end{tabular}

\subsection{Two-Step Cluster}

Two-Step Cluster merupakan metode yang dapat menangani variabel kategori dan kontinu (Şchiopu, 2010). Terdapat dua proses yang dilakukan yaitu pre-clustering dan clustering (Bacher, Wenzig, \& Vogler, 2004; Şchiopu, 2010; Wu, Zhan, Zhang, \& Deng, 2016; Li \& Sun, 2018). Pada proses pre-clustering, dilakukan pengecekan satu per satu data ke-0 sampai ke $\mathrm{N}$ untuk menentukan posisi apakah data tersebut masuk ke dalam cluster yang telah ada atau akan membentuk cluster baru sesuai dengan kriteria jarak (Şchiopu, 2010). Penentuan jarak dapat menggunakan beberapa metode pengukuran seperti jarak Euclidean atau log-likehood. Jarak Euclidean hanya dapat menangani data kontinu (Şchiopu, 2010), sehingga pada penelitian ini penentuan jarak menggunakan log-likelihood (Tumbaz \& Moğulkoç, 2018). Berikut merupakan rumus jarak log-likelihood (Li \& Sun, 2018).

$$
\begin{aligned}
& d(i, j)=\varepsilon_{i}+\varepsilon_{j}-\varepsilon_{(i, j)} \\
& \varepsilon_{i}=-n_{i}\left(\sum_{k=1}^{K} \frac{1}{2} \log \left(\dot{\sigma}_{i k}^{2}+\dot{\sigma}_{k}^{2}\right)\right) \\
& \varepsilon_{j}=-n_{j}\left(\sum_{k=1}^{K} \frac{1}{2} \log \left(\ddot{\sigma}_{j k}^{2}+\tilde{\sigma}_{k}^{2}\right)\right) \\
& \varepsilon_{(i, j)}=-n_{(i, j)}\left(\sum_{k=1}^{K} \frac{1}{2} \log \left(\left(_{i, j k}^{2}+\tilde{\sigma}_{k}^{2}\right)\right)\right.
\end{aligned}
$$

Persamaan (1) merupakan jarak antara cluster i dan $\mathrm{j}$ dengan indeks $\langle i, j\rangle$ merepresentasikan kombinasi dari cluster i dan j. Pada persamaan (2), (3), dan (4), K merupakan total dari variabel kontinu, dan $\tilde{\sigma}_{k}^{2}$ merupakan estimasi variansi dari keseluruhan data set, sehingga $\tilde{\sigma}_{i k}^{2}, \vec{\sigma}_{j k}^{2}$ dan $\tilde{\sigma}_{i, j k}^{2}$ merupakan estimasi variansi dari variabel kontinu $\mathrm{k}$ pada cluster i, j $\langle i, j\rangle$ (Li \& Sun, 2018; Şchiopu, 2010). Proses selanjutnya adalah dibentuknya struktur data menggunakan Cluster Feature (CF) Tree. $C F-T r e e$ terdiri dari tingkatan node dan setiap node mempunyai sejumlah entri. Node root, secara rekursif akan dikelompokkan ke dalam entri terdekat untuk menemukan simpul anak terdekat, lalu turun di sepanjang CF-Tree. Jika mendekati leaf node, maka akan dicari leaf entri terdekat. Leaf entri 
adalah final dari sub-cluster (Şchiopu, 2010; Zenina, Romanovs, \& Merkuryev, 2015).

Data hasil pre-clustering digunakan sebagai masukan untuk mencari cluster. Two-Step Cluster menggunakan metode hierarkis pada proses clustering. Untuk menentukan banyak cluster yang akan dibentuk, penelitian ini menggunakan indikator Schwarz's Bayesian Information Criterion (BIC). BIC digunakan untuk menemukan estimasi jumlah cluster dengan rasio jarak, di mana BIC merupakan informasi yang bersifat tepat (Mooi \& Sarstedt, 2011). Rumus BIC terlihat pada rumus (5) (Li \& Sun, 2018; Şchiopu, 2010).

$$
\operatorname{BIC}(j)=-2 \sum_{j=1}^{J} \xi_{j}+m_{j} \log (N)
$$

Pada rumus (5) ditunjukkan bahwa $\mathrm{j}$ adalah jumlah cluster, dengan $\mathrm{K}$ adalah jumlah variabel kontinu cluster, dan $\mathrm{N}$ adalah jumlah hasil observasi. Di mana $m_{j}=2 K J$. Setelah diketahui jumlah cluster, maka proses cluster dilakukan dengan menggabungkan hasil sub-cluster dari langkah preclustering sesuai dengan kriteria jarak yang ada sampai semua data tergabung dalam suatu cluster.

\section{HASIL DAN PEMBAHASAN}

Berikut merupakan hasil perhitungan dengan indikator BIC. Selain menentukan estimasi jumlah cluster, dilakukan juga penentuan kriteria, perubahan $\mathrm{BIC}$, rasio perubahan $\mathrm{BIC}$ dan rasio ukuran jarak seperti terlihat pada Tabel 2.

\begin{tabular}{|c|c|c|c|c|}
\hline $\begin{array}{l}\text { Jumlah } \\
\text { Cluster }\end{array}$ & $\begin{array}{l}\text { Schwarz's } \\
\text { Bayesian } \\
\text { Criterion } \\
\text { (BIC) }\end{array}$ & $\begin{array}{l}\text { Perubahan } \\
\text { BIC }\end{array}$ & $\begin{array}{l}\text { Rasio } \\
\text { Perubahan } \\
\text { BIC }\end{array}$ & $\begin{array}{l}\text { Rasio } \\
\text { Ukuran } \\
\text { Jarak }\end{array}$ \\
\hline 1 & 353.056 & & & \\
\hline 2 & 238.177 & -114.879 & 1.000 & 2.006 \\
\hline 3 & 194.615 & -43.561 & 0.379 & 1.910 \\
\hline 4 & 184.832 & -9.784 & 0.085 & 2.929 \\
\hline 5 & 199.488 & 14.656 & -0.128 & 1.056 \\
\hline 6 & 214.812 & 15.324 & -0.133 & 1.040 \\
\hline 7 & 230.602 & 15.790 & -0.137 & 1.657 \\
\hline 8 & 250.965 & 20.363 & -0.177 & 1.148 \\
\hline 9 & 272.225 & 21.260 & -0.185 & 1.154 \\
\hline 10 & 294.293 & 22.068 & -0.192 & 1.581 \\
\hline 11 & 318.293 & 23.999 & -0.209 & 1.470 \\
\hline 12 & 343.355 & 25.063 & -0.218 & 1.217 \\
\hline 13 & 368.820 & 25.465 & -0.222 & 1.169 \\
\hline 14 & 394.554 & 25.734 & -0.224 & 1.032 \\
\hline 15 & 420.337 & 25.783 & -0.224 & 1.362 \\
\hline
\end{tabular}

Tabel 2 merupakan hasil estimasi cluster yang terbentuk menggunakan indikator BIC. Terdapat 15 indikator berikut dengan detail perubahan jarak dan perhitungan jarak. Penentuan jumlah cluster pada BIC dilihat pada jarak rasio terbesar. Dari data yang ada jumlah cluster yang mempunyai rasio jarak terbesar adalah 4 cluster. Salah satu kelebihan TwoStep Cluster adalah dapat menemukan jumlah cluster yang paling optimal sesuai dengan data set yang ada (Mongi, 2015; Li \& Sun, 2018), di mana pada penelitian ini terbentuk jumlah cluster optimal yaitu 4 cluster yang terlihat dalam diagram scatter pada Gambar 2.

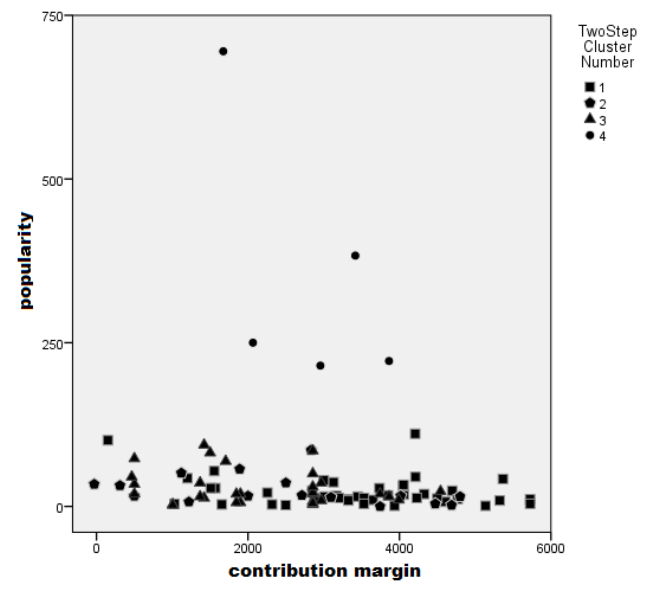

Gambar 2. Hasil Two-Step Cluster

Gambar 2 merupakan diagram scatter hasil cluster. Terdapat 4 cluster yang terbentuk berdasarkan popularity dan contribution margin. Cluster 1 diberikan simbol kotak, cluster 2 simbol bangun segilima, cluster 3 simbol segitiga dan cluster 4 simbol bulat. Selanjutnya untuk jumlah anggota pada masing-masing cluster dapat dilihat pada Tabel 3.

\begin{tabular}{ccc}
\multicolumn{3}{c}{ Tabel 3. Distribusi Cluster } \\
\hline Cluster & $\mathrm{N}$ & \% Kombinasi \\
\hline 1 & 42 & $44,2 \%$ \\
2 & 16 & $16,8 \%$ \\
3 & 32 & $33,7 \%$ \\
4 & 5 & $5,3 \%$ \\
Total & 95 & $100 \%$ \\
\hline
\end{tabular}

Tabel 3 menunjukkan jumlah frekuensi dan presentasi kombinasi item menu dari masing-masing cluster. Pada cluster 1 terdapat 42 item menu atau $44,2 \%$ dari keseluruhan item menu, sedangkan cluster 2 berisi 16 item menu atau 16,8\% dari keseluruhan item menu. Adapun cluster 3 berisi 32 item menu atau 33,7\% dari keseluruhan item menu, dan yang terakhir cluster 4 dengan frekuensi 5 item menu atau 5,3\% dari keseluruhan item menu. Daftar keanggotaan setiap cluster terlihat pada Tabel 4.

\begin{tabular}{clc} 
& \multicolumn{2}{c}{ Tabel 4. Keanggotaan Tiap Cluster } \\
\hline No & \multicolumn{1}{c}{ Item Dalam Cluster } & Total \\
\hline & {$[1,16,18,19,20,21,22,23,24,26$,} & \\
& $27,29,30,31,32,33,34,35,36,37$ & \\
Cluster 1 & $38,39,40,41,42,43,44,45,46,47$ & 42 \\
& $48,49,50,51,52,53,54,71,90,91$ & \\
& $92,93]$ & \\
& {$[25,28,70,74,75,76,77$} & \\
Cluster 2 & $78,79,80,83,84,85,86$ & 16 \\
& $87,88]$ & \\
& {$[2,3,4,5,6,7,8,9,10,11,12,13$,} & \\
Cluster 3 & $14,15,17,55,56,59,60,61,62,63$, & 32 \\
& $64,65,66,68,69,73$ & \\
& $81,82,94,95]$ & 5 \\
Cluster 4 & {$[57,58,67,72,89]$} &
\end{tabular}


Tabel 4 merupakan daftar keanggotaan tiap cluster. Sesuai dengan hasil cluster, tiap item dapat dikelompokan berdasarkan kategori sesuai popularity dan contribution margin. Kategori tiap cluster dideskripsikan di bawah ini.

\subsection{Cluster 1 (Low Popularity \& Above Average Contribution Margin)}

Cluster 1 merupakan cluster dengan 42 item didalamnya. Hasil perbandingan memperlihatkan bahwa item yang terdapat pada cluster ini mempunyai popularitas rendah tetapi mempunyai kontribusi margin di atas rata-rata. Perbandingan variabel dapat dilihat pada Gambar 3.

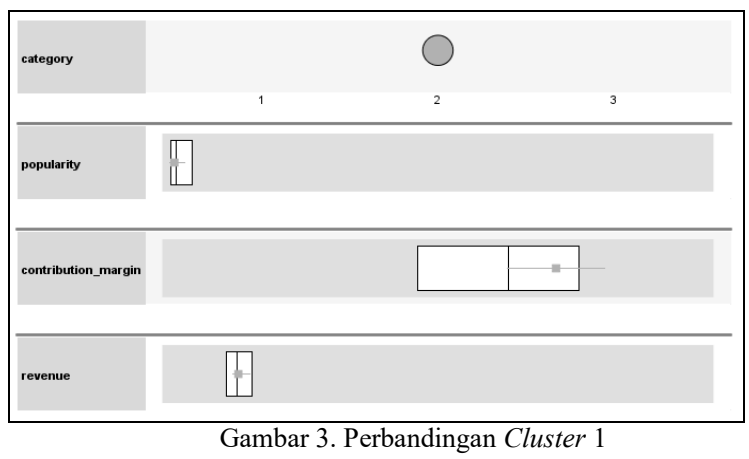

Gambar 3 merupakan hasil perbandingan dari variabel yang terdapat pada cluster 1. Item pada cluster 1 rata-rata berasal dari kategori item 2 yaitu minuman. Item pada cluster ini mempunyai popularitas yang belum mencapai rata-rata popularitas item lainnya tetapi item mempunyai margin kontribusi yang tinggi. Pada Gambar 3 terdapat variabel pendapatan (revenue) yang digunakan sebagai variabel evaluasi. Meskipun mempunyai margin kontribusi yang tinggi, karena popularitas rendah maka pendapatannya berada di rata-rata.

Pada cluster ini, beberapa kebijakan yang dapat dilakukan adalah: 1) Memberikan potongan harga pada aplikasi pesan antar makanan dan/atau mempromosikan menu tersebut melalui sosial media untuk menarik pelanggan; 2) Meningkatkan popularitas menu dengan cara meletakkan pada posisi strategis seperti ditampilkan pada layar penampil menu (Tom \& Annaraud, 2017) atau menawarkannya melalui pelayan ketika pelanggan memesan makanan atau minuman; 3) Mengganti nama menu dengan nama yang lebih menarik; 4) Meninjau kembali penetapan biaya di mana langkah selanjutnya yang bisa dilakukan adalah dengan menurunkan harga jual makanan dengan memperhatikan kondisi margin keuntungan, harga pokok penjualan, dan juga harga jual kompetitor; 5) Mempertimbangkan untuk menarik atau menghapus menu tersebut.

\subsection{Cluster 2 (Low Popularity \& Below Average Contribution Margin)}

Cluster 2 mempunyai 16 item didalamnya. Item-item menu pada cluster ini mempunyai popularitas rendah dan mempunyai margin kontribusi di bawah rata-rata. Perbandingan variabel dapat dilihat pada Gambar 4.

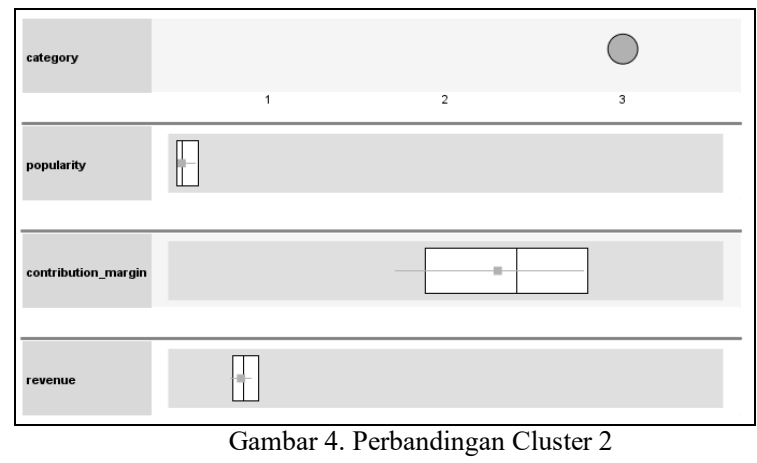

Gambar 4 merupakan perbandingan Cluster 2 di mana mempunyai item yang rata-rata terdapat pada kategori item 3 yaitu snack. Pendapatan dari itemitem menu pada cluster ini berada di bawah rata-rata. Beberapa kebijakan yang dapat dilakukan pada cluster ini adalah: 1) Mengganti nama menu dengan nama yang lebih menarik; 2) Menghapus menu yang ada (Tom \& Annaraud, 2017), di mana kebijakan ini merupakan alternatif untuk mengurangi beban usaha yang besar; 3) membuat paket menu dari cluster ini yang digabungkan dengan makanan atau minuman dari cluster lain yang memiliki popularitas tinggi (Adiatma, Andriatna, \& Sudono, 2014) terutama pada cluster High Popularity \& Above Average Contribution Margin. Dalam suatu usaha kuliner, jumlah item menu pada cluster ini harus diminimalisir karena akan menambah beban biaya keseluruhan.

\subsection{Cluster 3 (High Popularity \& Below Average Contribution Margin)}

Cluster 3 mempunyai 32 item menu didalamnya. Hasil perbandingan variabel pada Cluster 3 dapat dilihat pada Gambar 5.

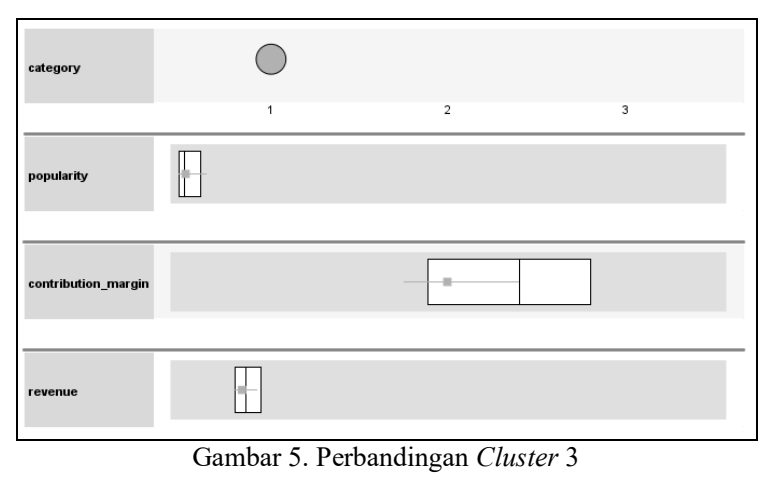

Gambar 5 menunjukan bahwa rata-rata item menu pada cluster ini masuk pada kategori item 1 
yaitu makanan. Cluster ini menunjukkan kelompok item menu dengan popularitas tinggi tetapi memiliki margin kontribusi di bawah rata-rata sehingga menghasilkan pendapatan yang rendah. Adapun kebijakan yang dapat dilakukan adalah: 1) Mempertahankan kualitas makanan serta penampilan sesuai dengan standar resep yang berlaku; 2) Melakukan peninjauan kembali penetapan biaya (Tom \& Annaraud, 2017) seperti dengan melakukan penekanan biaya melalui pengawasan dalam jumlah pemesanan bahan, efisiensi pengolahan serta melakukan simplifikasi penyajian dengan tetap mempertahankan kualitas dan estetika tampilan makanan; 3) Menaikkan harga jual makanan secara bertahap dengan memperhatikan jumlah permintaan.

\subsection{Cluster 4 (High Popularity \& Above Average Contribution Margin)}

Cluster 4 merupakan kelompok item menu yang memiliki popularitas yang tinggi dan margin kontribusi di atas rata-rata. Perbandingan hasil cluster terlihat pada Gambar 6.

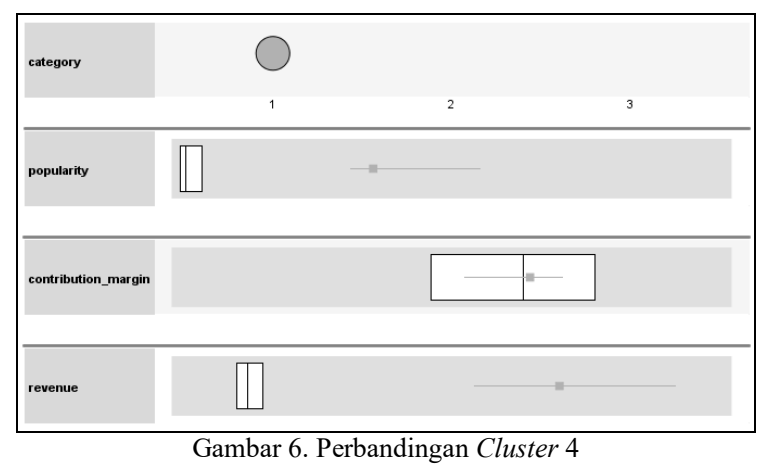

Cluster 4 mempunyai 5 anggota didalamnya yaitu item 57, item 58, item 67, item 72 dan item 89. Cluster 4 mempunyai item yang rata-rata berada di kategori makanan. Cluster ini menghasilkan pendapatan yang tinggi. Kebijakan yang dapat dilakukan pada cluster ini adalah: 1) Mempertahankan kualitas menu, porsi, serta penampilan sesuai standar resep yang berlaku (Tom \& Annaraud, 2017); 2) Menaikkan harga jual secara berkala dengan memperhatikan peningkatan permintaan yang ada serta harga jual dari pesaing; 3) Memantau kenaikan harga bahan baku menu dan menyesuaikan dengan harga jual menu.

Untuk melihat validitas clustering, dilakukanlah pengujian menggunakan Silhoutte. Silhoutte adalah salah satu metode terbaik dalam memilih jumlah cluster yang optimal (Jauhiainen \& Tommi, 2017) dengan data skala rasio yang cocok untuk pemisahan cluster yang jelas (Thinsungnoen, Kaoungku, \& Durongdumronchai, 2015). Adapun hasil pengujian validitas clustering menggunakan Silhoutte terlihat pada Gambar 7.

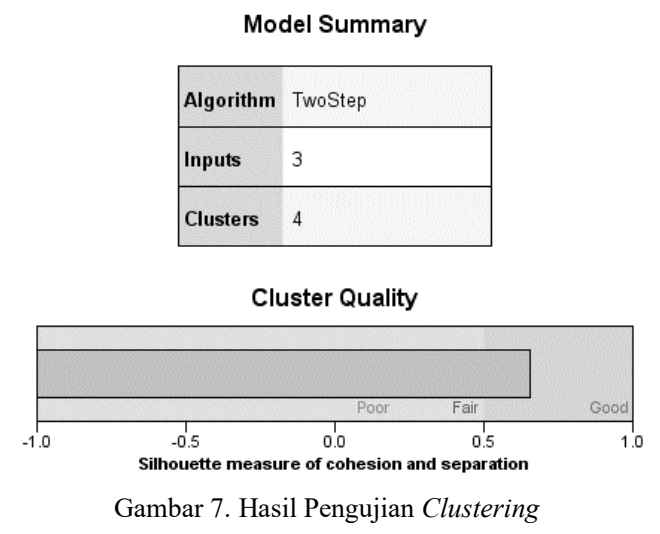

Gambar 7 adalah hasil pengujian clustering menggunakan metode Silhoutte, di mana terlihat bahwa kualitas cluster yang dihasilkan memiliki nilai Silhoutte yang besar yaitu 0,7. Hal ini membuktikan cluster-cluster yang terbentuk telah terklasterisasi dengan baik (Xu dkk., 2016).

\section{KESIMPULAN}

Proses pengklasteran menggunakan Two-Step Cluster memberikan kemudahan dalam analisis data karena mengakomodir variabel kategori dan variabel kontinu serta menghasilkan jumlah cluster yang optimal karena disesuaikan dengan kondisi data set. Pada penelitian ini, terdapat 4 cluster yang terbentuk sesuai dengan kesamaan kriteria di tiap item set. Hasil cluster dikategorikan sesuai popularity dan contribution margin dengan menambahkan variabel revenue yang mampu memberikan analisis yang lebih jelas terhadap kondisi setiap cluster yang terbentuk. Selain itu juga dilakukan penambahan variabel category untuk menambahkan spesifik hasil cluster dan melihat mayoritas kategori menu yang menjadi anggota pada setiap cluster. Two-Step Cluster juga dapat menemukan cluster yang paling optimal sesuai dengan varian data set.

Terdapat cluster yang paling menonjol (outstanding) yaitu pada cluster High Popularity \& Above Average Contribution Margin yang memiliki 5 item set dengan memberikan pendapatan yang tinggi untuk UMKM tersebut. Dari cluster-cluster yang yang dihasilkan, dapat diberikan rekomendasi kebijakan baru untuk pemilik UMKM untuk peningkatan revenue usaha.

\section{DAFTAR PUSTAKA}

ADIATMA, D., ANDRIATNA, W., SUDONO, A., 2014. Analisis Perbaikan Menu Unpopular Di Restoran Dapur Sunda Di Kota Jakarta. Gastronomy Tourism, 1 (1), pp. 35-48. [online] Tersedia di: http://ejournal.upi.edu/index.php/gastur/ar ticle/view/4654 [Diakses 11 Februari 2019].

ATKINSON, H., JONES, P., 1994. Menu Engineering: Managing the Foodservice 
Micro-Marketing Mix. Journal of Restaurant and Foodservice Marketing, 1 (1), pp. 37-55.

BICIKOVA, K., 2014. Understanding Student Travel Behavior : A Segmentation Analysis of British University Students. Journal of Travel \& Tourism Marketing, 31 (7), pp. 854-867. Tersedia melalui: https://doi.org/10.1080/10548408.2014.89 0154 [Diakses pada 29 Juni 2019].

COHEN, E., MESIKA, R., SCHWARTZ, Z., 1998. A Multidimensional Approach to Menu Sales Mix Analysis, Praxis, 2 (1), pp. 130-144.

HAYES, D.K., HUFFMANN, L., 1985. Menu Analysis: A Better Way. The Cornell Hotel and Restaurant Administration Quarterly, 25 (4), pp. 64-70.

HERNOWO, A., 2014. Rekayasa Menu di Katumiri Coffee Shop The Travelhotel Cipaganti Bandung. Jurnal Kajian Bahasa dan Pariwisata, 1 (2). Tersedia melalui: http://stp-

bandung.ac.id/ejournal/index.php/v01/arti cle/view/21 [Diakses 30 Juni 2019].

HORN, B. B., \& HUANG, W., 2016. Comparison of Segmentation Approaches. Tersedia melalui:

https://www.decisionanalyst.com/media/d ownloads/marketsegmentationcomparison .pdf [Diakses pada 29 Juni 2019].

JAUHIAINEN, S., TOMMI, K., 2017. A Simple Cluster Validation Index with Maximal Coverage. ESANN 2017 proceedings, European Symposium on Artificial Neural Networks, Computational Intelligence and Machine Learning, pp. 293-298. Tersedia melalui

https://www.elen.ucl.ac.be/Proceedings/es ann/esannpdf/es2017-24.pdf [Diakses pada 30 Juni 2019].

LEBRUTO, S.M., QUAIN, W.J., ASHLEY, R.A., 1995. Menu engineering: A model including labor, Hospitality Review, Vol.13, Issue 1, pp. 41-49. [online] Tersedia

di: http://digitalcommons. fiu.edu/hospitalityr eview/vol13/iss1/5 [Diakses 10 Januari 2019].

LI, G., SUN, L., 2018. Characterizing Heterogeneity in Drivers' Merging Maneuvers Using Two-Step Cluster Analysis. Journal of Advanced Transportation. [online] Tersedia di: https://www.hindawi.com/journals/jat/201 8/5604375/ [Diakses 2 Februari 2019].

LINASSI, R., ALBERTON, A., MARINHO, S. V., 2016. "Menu Engineering and ActivityBased Costing: An Improved Method of Menu Planning", International Journal of
Contemporary Hospitality Management, 28 (7), pp. 1417-1440.

KASAVANA, M.L., SMITH, D. I., SCHMIDGALL, R.S., 1990. Menu Engineering : A Practical Guide to Menu Analysis. Rev ed. Okemos, Mich. : Hospitality Pub.

MONGI, C. E., 2015. Penggunaan Analisis Two Step Clustering untuk Data Campuran. D'cartesian : Jurnal Matematika dan Aplikasi, 4 (1), pp. 9-19. Tersedia melalui https://ejournal.unsrat.ac.id/index.php/dec artesian/article/view/7251/6754 [Diakses pada 30 Juni 2019].

MOOI, E., SARSTEDT, M.2011. A Concise Guide to Market Research. Springer: Heidelberg, Germany, pp. 237-284

OJUGO, C., 2009. Practical Food and Beverage Cost Control, 2nd Edition. United Kingdom: Delmar Cengage Learning.

OZDEMIR, B., CALISKAN, O., 2014. A Review of Literature on Restaurant Menus: Specifying The Managerial Issues. International Journal of Gastronomy and Food Science.

RAAB, C., MAYER, K., 2007. Menu Engineering and Activity-Based Costing-Can They Work Together in A Restaurant?", International Journal of Contemporary Hospitality Management, 19 (1), pp.4352.

ŞCHIOPU, D., 2010. Applying TwoStep Cluster Analysis for Identifying Bank Customers' Profile. Buletinul Universitatii PetrolGaze din Ploiesti, Seria Stiinte Economice, LXII(3), pp. 66-75. [online] Tersedia di: http://www.upg-bulletinse.ro/archive/2010-3/7.\%20Schiopu.pdf [Diakses 11 Februari 2019].

SEYITOGLU, F., 2016. A Conceptual Study on Menu Planning and The Selection of Menu Items. Proceedings of The 7th MAC 2016, pp. 183-191.

SORIANO, A., KOZUSZNIK, M.W., PEIRO, J.M., 2018. From Office Environmental Stressors to Work Performance: The Role of Work Patterns. International Journal of Environmental Research and Public Health, 15(8). [online] Tersedia di: https://www.mdpi.com/16604601/15/8/1633 [Diakses 7 Maret 2019].

TAYLOR, J.J., BROWN, D.M., 2007. Menu Analysis: A Review of Techniques and Approaches. Hospitality Review, 25 (2), pp. 74-82. Tersedia melalui: https://digitalcommons.fiu.edu/hospitalit yreview/vol25/iss2/6 [Diakses 10 Maret 2019].

THINSUNGNOEN, T., KAOUNGKU, N., \& DURONGDUMRONCHAI, P., 2015. 
The Clustering Validity with Silhouette and Sum of Squared Errors. Proceedings of the 3rd International Conference on Industrial Application Engineering. pp. 44-51. Tersedia melalui: https://www.researchgate.net/publication/ 300699735_The_Clustering_Validity_wi th_Silhouette_and_Sum_of_Squared_Err ors [Diakses pada 30 Juni 2019].

TOM, M., ANNARAUD, K., 2017. A fuzzy multicriteria decision making model for menu engineering. 2017 IEEE International Conference on Fuzzy Systems (FUZZIEEE), Naples, Italy, pp.1-6.

TUMBAZ, M. N. M., \& MOĞULKOÇ, H.T., 2018. Profiling Energy Efficiency tendency: A case for Turkish Households. Energy Policy, Elsevier, 119(C), pp. 441-448.

XU, S., QIAO, X., ZHU, L., ZHANG, Y., XUE, C., \& LI, L., 2016. Reviews on Determining the Number of Clusters. Applied Mathematics \& Information Sciences, 10 (4), pp. 1493-1512. Tersedia melalui: http://www.naturalspublishing.com/files/ published/y9251mj6n8vs9h.pdf \{Diakses pada 30 Juni 2019].

WU, X., ZHAN, F. B., ZHANG, K., DENG, Q., 2016. Application of a Two-Step Cluster Analysis and The Apriori Algorithm to Classify the Deformation States of Two Typical Colluvial Landslides in the Three Gorges, China" Environmental Earth Sciences, 75 (2), pp. 146.

ZENINA, N., Romanovs, A., Merkuryev, Y., 2015. Transport Simulation Model Calibration with Two-Step Cluster Analysis Procedure. Information Technology and Management Science, 18 (1), pp. 49-56. [online] Tersedia di: https://ortus.rtu.lv/science/en/publicat ions/22120-

Transport+Simulation+Model+Calibr ation+with+Two-

Step + Cluster+Analysis + Procedure [Diakses 12 Januari 2019]. 